\title{
Load and failure behavior of human muscle samples in the context of proximal femur replacement
}

\author{
Stefan Schleifenbaum ${ }^{1 \dagger}$, Michael Schmidt ${ }^{1 \dagger}$, Robert Möbius², Thomas Wolfskämpf ${ }^{2}$, Christian Schröder ${ }^{3}$, \\ Ronny Grunert ${ }^{4}$, Niels Hammer ${ }^{5^{*+}}$ and Torsten Prietzel $^{1+}$
}

\begin{abstract}
Background: To ensure adequate function after orthopedic tumor reconstruction, it is important to reattach the remaining soft tissue to the implant. This study aimed at obtaining mechanical properties of textile muscle-implant and muscle-bone connections in a preliminary test.

Methods: Two groups of soft-tissue attachment were mechanically tested and compared: Native bone-muscle samples obtained from human femora and muscles attached to a prosthetic implant by means of Trevira ${ }^{\circledR}$ attachment tubes. Additionally, muscle samples were tested with muscle fibers aligned parallel and perpendicular to the tension load. A uniaxial load was exerted upon all samples.

Results: Failure loads of $26.7 \pm 8.8 \mathrm{~N}$ were observed for the native bone-muscle group and of $18.1 \pm 9.9 \mathrm{~N}$ for the Trevira ${ }^{\circledR}$ group. Elongations of $94.8 \pm 36.2 \%$ were observed for the native bone-muscle group and $79.3 \pm 51.8 \%$ for the Trevira ${ }^{\oplus}$ group. The location of failure was mainly observed in the central area of the muscle fibers. Muscle fibers with parallel fiber orientation $(47.6 \pm 11.5 \mathrm{~N})$ yielded higher tensile strength than those with perpendicular fiber orientation $(14.8 \pm 4.1 \mathrm{~N})$.

Conclusions: Our experiments showed that higher forces were transmitted in the origin and insertion areas than in areas of flat soft tissue reconstruction using attachment tubes. The data indicate that the tested material allows reattaching muscles, but without reinforcing the insertion site. Therefore, attachment tubes with region-dependent and potentially anisotropic material behavior might be advantageous to optimize muscle-bone load transmission after surgery, which may allow lower complication rates and shorter physical recovery.
\end{abstract}

Keywords: Mechanical properties, Muscle-bone connection, Muscle-attachment tubes, Proximal femoral reconstruction, Tumor orthopedic

\section{Background}

Modular tumor prostheses allow for limb-sparing techniques in the curative treatment of most primary malignant bone tumors. Prosthetic reconstruction may also help maintain or regain mobility in palliative cases involving bone metastasis. Modular prostheses are commonly used for bone and joint reconstruction [1-3],

\footnotetext{
* Correspondence: nlshammer@googlemail.com

Stefan Schleifenbaum and Michael Schmidt contributed equally to this publication.

Niels Hammer and Torsten Prietzel contributed equally to this publication.

${ }^{\dagger}$ Equal contributors

${ }^{5}$ Department of Anatomy, University of Otago, Lindo Ferguson Building, 270

Great King St., Dunedin 9016, New Zealand

Full list of author information is available at the end of the article
}

making it possible to avoid amputation in the majority of cases. After the resection of the invaded parts of the bones and joints, orthopedic surgery aims at restoring joint and muscle function to resemble the healthy state as closely as possible. With this goal in mind, to enhance postoperative stability and to avoid complications, it is essential to reattach the remaining muscles, tendons, ligaments and aponeuroses to the tumor prosthesis, creating a load-bearing compound [4,5]. Available tumor prosthesis systems, however, only provide limited sites for soft tissue reattachment. The soft tissue connection reached by suture and eyelets is often unsatisfactory [6]. The resulting gap, potentially containing hematoseroma, increases the risk of infection through bacterial 
colonization [5, 7-10]. An alternative fixation of the soft tissues can be accomplished by suturing them onto the tumor prosthesis by means of attachment tubes. Attachment tubes enable a stable muscle connection on the whole tumor prosthesis by primary suture as well as secondary scar tissue ingrowth [4,11-13]. One of the main fields of application of such tube-like implants is the region of the proximal femur (Fig. 1). Here, the gluteus and the vastus muscle groups can be reattached following extensive bone removal [1].

However, the acting forces and failure mechanisms in the muscle-implant interface have only been investigated to a limited extent. Existing research mainly focuses on the origin and attachment of muscles. Such data could help establish an objective basis for further development of current connection systems. This study aimed at collecting data on mechanical load and failure behavior of textile muscle-implant connections and compared these data to native muscle-bone connections. Furthermore, this study aimed at analyzing the influence of muscle fiber orientation on strain and failure behavior, which is well established using animal-based data [14, 15], but has not been shown using human tissue.

The following hypotheses were examined:

(1)Artificial connections between muscles and attachment tubes withstand a comparable level of tensile forces and strain as the native muscle-bone connections.

(2) Passive tensile material properties of human muscle tissue are strongly dependent on the fiber direction.

\section{Methods}

\section{Sample acquisition and preparation}

The quadriceps femoris muscle and the adjacent femur were removed from two body donors (A: 90 year-old



male B: 66 year-old male; Fig. 1) at the Institute of Anatomy, University of Leipzig, Germany. While alive, the donors gave their informed and written consent to the post-mortem donation of their bodies for teaching and research purposes. Being part of the body donor program regulated by the Saxonian Death and Funeral Act of 1994 (third section, paragraph 18 item 8), institutional approval for the use of the post-mortem tissues of human body donors was obtained from the Institute of Anatomy, University of Leipzig. The authors declare that all experiments have been conducted according to the principles of the Declaration of Helsinki. The donors had no history of connective tissue disease and the tissues were removed in a fresh and chemically-unfixed condition with a post-mortem delay of less than $24 \mathrm{~h}$. The muscle samples were processed in a condition without rigor mortis [16]. The femora and muscles were immediately moistened with isotonic sodium chloride solution, precooled at $3^{\circ} \mathrm{C}$ and shock frozen at $-85^{\circ}$ C. Sixty-five serial sections of the muscles and bones of $30 \mathrm{~mm}$ thickness were obtained from the donors (A: 32 and $\mathrm{B}: 33$ sections). The samples were randomly assigned to one of the following two test series: a connection test series and a muscle test series. The connection test series (Fig. 2) was further subdivided into a bone-muscle interface group and a Trevira ${ }^{\circ}$ group, each consisting of 17 samples. The muscle test series (Fig. 3) was further subdivided into a parallel group and a perpendicular group, according to the muscle fiber orientation in relation to the force vector. The muscle group consisted of 15 samples in parallel direction and 16 samples in perpendicular direction. In all subgroups the muscle ends were partially plastinated.

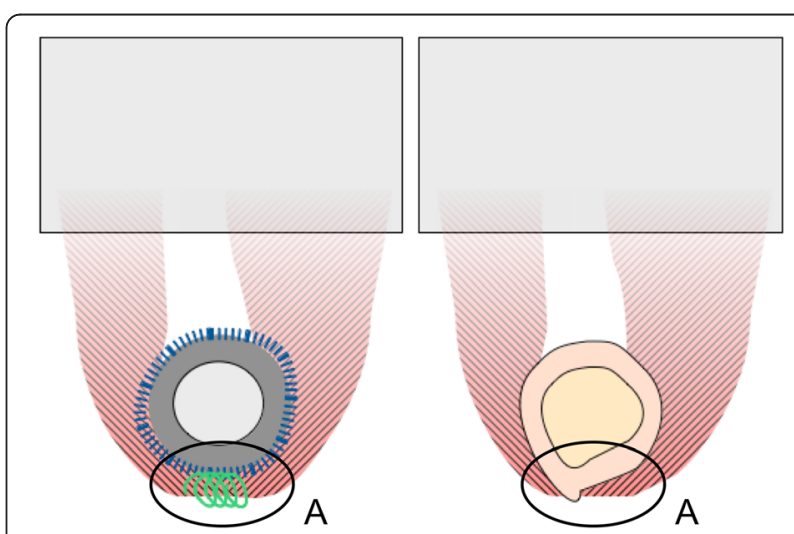

Fig. 2 Schematic sketch of connection test series (red - muscle, grey partial plastination area): left: Trevira ${ }^{\oplus}$ group (blue - attachment tube, green - suture material, dark grey - implant model); right: bone-muscle interface group ; $\mathbf{a}$ : transition to the Trevira ${ }^{\oplus}$ textile and muscle-bone insertion site 


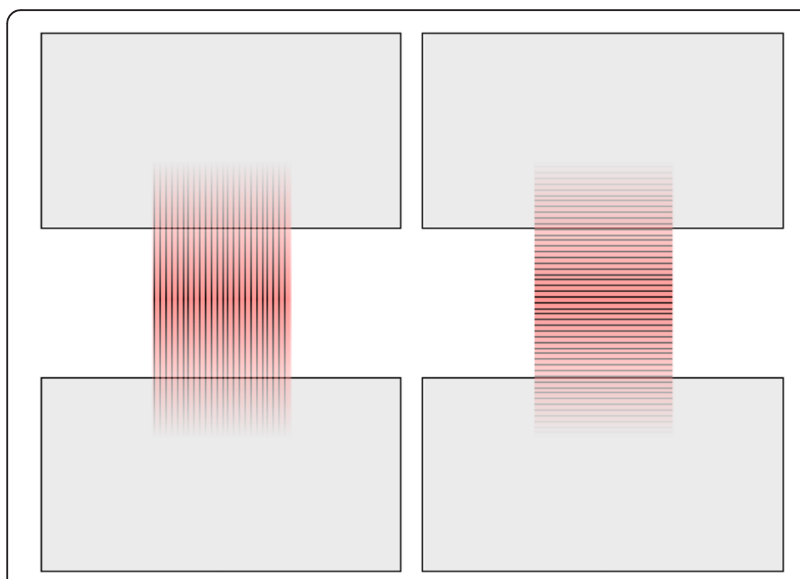

Fig. 3 Schematic sketch of muscle group (red - muscle with fiber orientation, grey - partial plastination area): left: parallel group; right: perpendicular group

\section{Partial plastination technique}

The ends of the muscle and muscle-bone samples were freeze-substituted in acetone and primed with polyurethane resin in a ratio of $1 / 1 / 3$ with RENCAST FC52 Isocyanate/FC52 Polyol/Ceramic Powder (RenShape solutions, Huntsman International LLC, Salt Lake City, USA;). The resin was reinforced with Pertinax plates (PF CP 201, Dr. Müller GmbH, Ahlhorn, Germany) to improve the stability of the plastinated parts for clamping in the material testing machine (Figs. 2 and 3). After polymerization of the resin, the samples were rinsed in $40{ }^{\circ} \mathrm{C}$ water to remove the gelatin. The central parts of the samples remained in an anatomically unfixed and fresh condition at all times. The resulting samples measured 20 or more millimeters in length and 14 or more millimeters in width. For more details on the partial plastination technique, please refer to [17] and [18]. For further storage prior to the mechanical testing, the samples were immediately precooled at $3{ }^{\circ} \mathrm{C}$ and shock frozen at $-85{ }^{\circ} \mathrm{C}$. This approach prevented the formation of ice needles, potentially influencing material properties $[16,19]$.

\section{Mechanical testing}

The samples that were used for the Trevira ${ }^{\circ}$ group in the connection test series were dissected immediately prior to the tensile tests. The muscle tissue surrounding the bone was severed from the aponeurosis and detached along the bone. Subsequently a $40-\mathrm{mm}$ long piece of textile tube connection made of polyethylene terephthalate with a diameter of $35 \mathrm{~mm}$ (Trevira', Implantcast, Buxtehude, Germany) was put on a steel cylinder with a diameter of $30 \mathrm{~mm}$. The previously detached muscle endings were laid around the textile and stitched using a standardized double knot technique according to the intraoperative standard operating procedure [20]. As suture material, polyester stitches (Mersilene ${ }^{\bullet} 3$, Somerville, NJ, USA) were used. The muscle samples were tapered in their central part prior to the mechanical tensile testing.

Uniaxial tensile tests were obtained from all muscle samples (Fig. 4). On the day of testing, the samples were defrosted for two hours in isotonic sodium chloride solution $\left(37^{\circ} \mathrm{C}\right)$ and were immediately taken out for testing. The tensile tests were performed using an electro-mechanical testing machine (Typ 5566A, Instron, Norwood, MA, USA), a $1 \mathrm{kN}$ load cell and the software for data acquisition on the basis of a speckle pattern sprayed on the samples (Blue Hill 2.0, Instron, Norwood, MA, USA). The plastinated ends of the samples were clamped between the jaws. For further standardization, a pretension of $3 \mathrm{~N}$ was set and then the cross-section of the sample was measured with a caliper. Specimen dimensions were obtained individually for each sample before the testing started. For this purpose a reference image was made with camera system (Limess Meßtechnik und Software GmbH, Krefeld, Germany). The testing velocity was $20 \mathrm{~mm} / \mathrm{min}$ with a sampling rate of $10 \mathrm{~Hz}$, according to data previously published elsewhere [18, 21]. For qualitative failure localization, the camera system was recorded during the test with a sample rate of $5 \mathrm{~Hz}$.

\section{Data processing and statistical analysis}

The stress-strain values were computed using MATLAB 2011 (Mathworks, Natick, MA, USA). The elastic modulus was calculated with the secant modulus and the elongation with Cauchy-elongation. Elastic modulus, ultimate strain $\left(\mathrm{F}_{\mathrm{Max}}[\mathrm{N}]\right)$ and elongation $\left(\varepsilon_{\mathrm{FMax}}\right.$ [\%]) during the maximum strain were calculated on the basis of the stress-strain data for the muscle test series. For the connection test series, only the ultimate strain $\left(\mathrm{F}_{\mathrm{Max}}[\mathrm{N}]\right)$ and elongation $\left(\varepsilon_{\mathrm{FMax}}[\%]\right)$ were calculated. Statistical comparison of the data was performed using the SPSS 20.0 software (IBM, IL, USA). The KolmogorovSmirnov test (KS) was used to determine normal distribution of the data, followed by the Mann-Whitney U-test. $P$-values of 0.05 or less were considered being statistically significant.

The digital image analysis data were exclusively used for the qualitative localization of the failure site. Therefore, two major areas were distinguished in the samples: Proximity to the muscle-bone insertion site of attachment or the textile (failure location A, Fig. 2) and in the central/neutral muscle area (failure location B).

\section{Results}

Stress-strain data of 62 samples were obtained. Data of three samples were excluded: one sample in the bonemuscle group, one in the Trevira ${ }^{\circ}$ group and one in the 



Fig. 4 Experimental setup with three different sample types: Left: Alignment of the muscle fibers parallel to the tension load. Middle: The bone was attached at the lower clamp while the plastinated muscle end was clamped on top. Right: The connection tube was pulled over the metallic cylinder, while the sutures that connect the muscle to the tube were aligned downwards to the cylinder

perpendicular muscle group due to material slippage and failure outside the tapered area.

\section{Connection test series}

The primary location of failure was in the central area of $87.5 \%$ of the muscle bone and Trevira ${ }^{\circ}$ groups, as indicated by the camera system. In the remaining $12.5 \%$ (Fig. 2a), the failure site was located in proximity to the muscle-bone insertion site or at the transition to the Trevira ${ }^{\circ}$ textile. In the bone-muscle group, a mean maximum force of $26.7 \pm 8.8 \mathrm{~N}$ (mean \pm standard deviation) and a strain under maximum force absorption $\varepsilon_{\text {Fmax }}$ of $94.8 \pm 36.2 \%$ were recorded. In the Trevira ${ }^{\circ}$ group, $F_{\max }$ was $18.1 \pm 9.9 \mathrm{~N}$ and $\varepsilon_{\mathrm{Fmax}}$ was $79.3 \pm 51.8 \%(p=0.026$; $p=0.379$, Fig. 5). Load-to-failure graphs are exemplarily shown in Fig. 6.

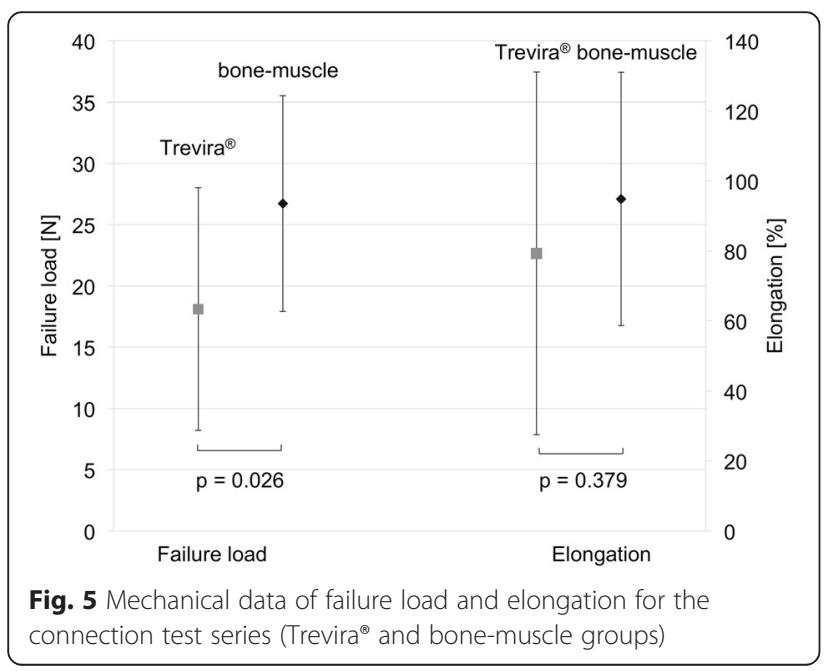

\section{Muscle test series}

In both muscle groups, the primary failure site was found in the central area of the samples, regardless of the fiber orientation. Muscle samples with fiber orientation parallel to the strain direction yielded significantly higher maximum forces of $47.6 \pm 11.5 \mathrm{~N}$, as compared to the samples with perpendicular fiber orientation, averaging of $14.8 \pm 4.1 \mathrm{~N}(p<0.001)$. The strain during the maximum force absorption was $66.4 \pm 27.6 \%$ (parallel) and $52.6 \pm 27.1 \%$ (perpendicular), differing to a non-statistically significant level ( $p=0.186$; Fig. 7). Elastic moduli of $26.6 \pm 14.0 \mathrm{kPa}$ (parallel) and $10.6 \pm 5.2$ $\mathrm{kPa}$ (perpendicular) were derived. Load-to-failure graphs are exemplarily shown in Fig. 8.

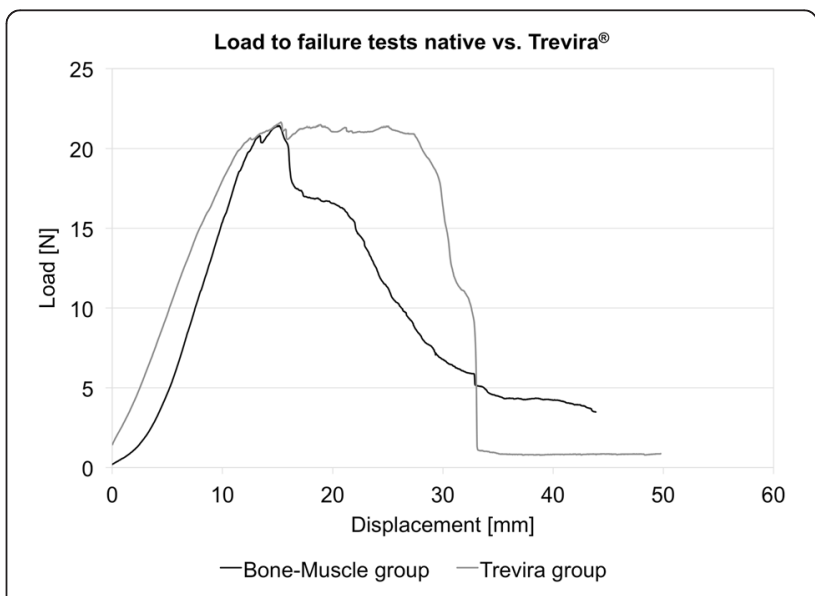

Fig. 6 Representative example of failure load graphs for the native bone-muscle group and for the Trevira ${ }^{\oplus}$ group 


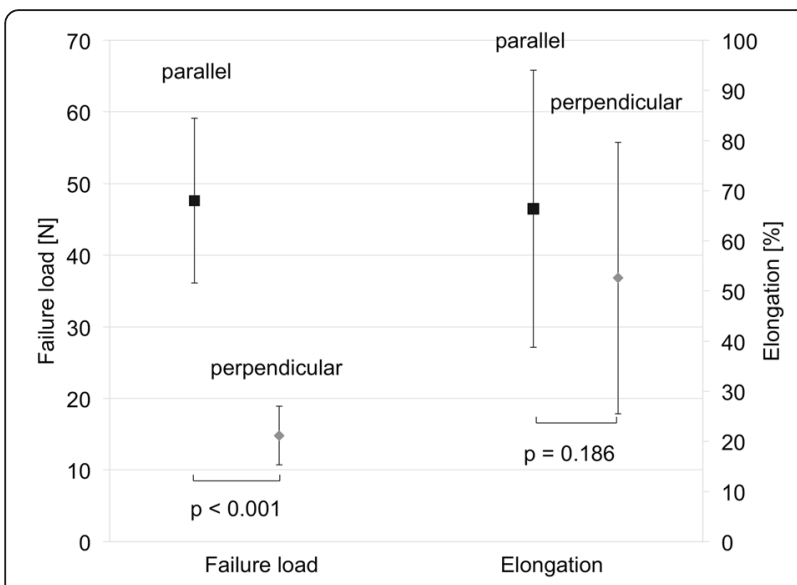

Fig. 7 Mechanical data of failure load and elongation for the muscle test series (parallel and perpendicular muscle fiber orientation)

\section{Discussion}

The Trevira ${ }^{\circledR}$ group showed significantly lower failure loads than the muscle-bone group while undergoing passive strain

This study examined the failure mechanisms of human muscle samples, depending on the type of attachment chosen for soft tissue reconstruction. The principal aim was to determine to what extent the strain that soft tissue attached to tumor prosthesis by means of textile connections resembles the strain withstood by native muscle-bone attachments in similar scenarios. Furthermore, for comparative purposes, mechanical tensile load-strain values of human post-mortem muscle tissue were collected in the context of fiber orientation. The samples of the Trevira ${ }^{\oplus}$ group showed significantly lower failure loads than the muscle-bone group, indicating that the removal of the original muscle attachment decreases the strength of the connection interface as well. These findings coincide with literature in which artificially

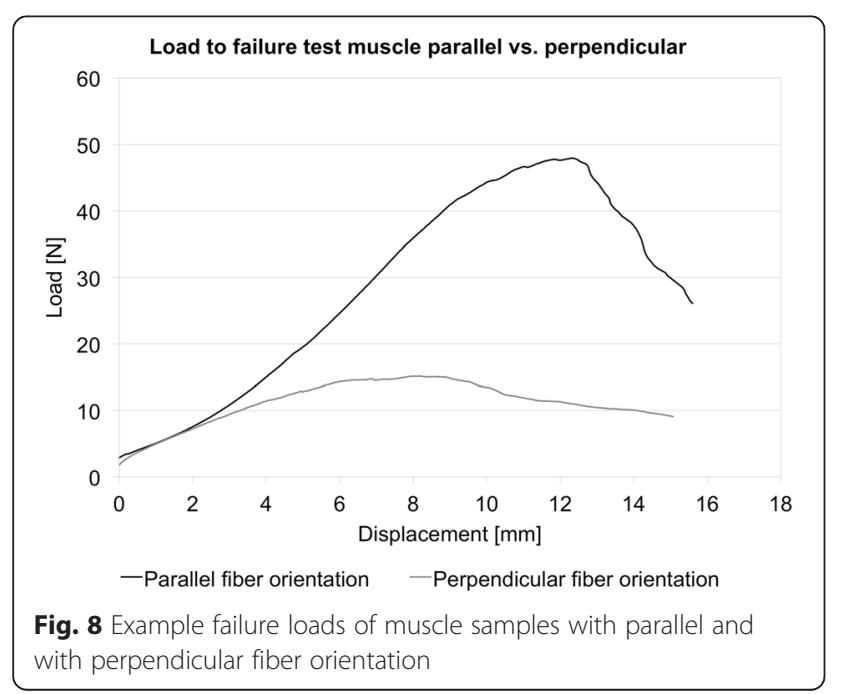

reconstructed joint structures show a significantly lower strength than the physiological structures [22]. Hypothesis 1 therefore has to be rejected on the basis of the tensile data obtained in our study. Furthermore, high variances were observed in the strain data by the Trevira ${ }^{\oplus}$ and muscle-bone group. Possible reasons for this finding were the regionally different tissue properties of muscles obtained from the femur of the body donors. Also the strain may be influenced by the by different ages of the two subjects [23]. The location of failure was almost exclusively in the region of the muscle tissue. Surprisingly, tears were found at the connection site or at the transition between muscle and textile in $10 \%$ of all cases. These findings suggest that the reattachment through sutures reinforces the muscle tissue, promoting material failure outside of the region of the suture. The existing literature shows higher tensile strength and elasticity in ligaments and tendons $[17,24,25]$ than the muscle samples in our study. Artificial textile connections are also likely to have significantly higher tensile strengths $[26,27]$.

\section{Passive tensile strength of muscle samples is orientation-dependent concerning the passive properties of muscle fibers}

The highest tensile strength was found when a load was applied parallel to muscle fiber orientation, corresponding to the natural stress direction within the muscle tissue. Significantly higher forces could be absorbed in fibers aligned parallel to the strain vector, as compared to the perpendicular fiber orientation. This might be due to the fact that the muscles were also subject to tensile stress during physiological contraction [28-30]. However, this observation is limited to the passive mechanical properties of muscles. The elastic moduli obtained from the muscle samples with parallel fiber orientation were similar to the values obtained by Kot and coworkers [31], with minor differences likely attributable to the freeze thawing cycles causing a decrease of approximately $40 \%$ [19]. Hypothesis two can therefore be accepted. Similar findings have been obtained in muscle samples of pigs $[14,15]$, whereas our study used muscle samples from humans.

A trend to higher elongations was observed in muscle samples with parallel fiber orientation as compared to muscle samples being strained perpendicularly to the fiber orientation. The highest elongation values were found in the parallel muscle group. It is known that in physiological contraction muscle fibers shorten to a varying extent, depending on the joint angle and their pennation angles [29, 30, 32]. Simultaneously occurring shear loads in the region of the bony attachments might be the reason for a significantly higher maximum elongation in the parallel direction [28, 33, 34]. Additionally, 
the insertion of suture materials seems to significantly reduce the strain, as compared to physiological connections. This might potentially be related to the sawing effects of the sutures.

\section{Clinical implications for the attachment of muscles in tumor surgery}

A major issue in orthopedic surgery is to create a highly durable surgical connection of biological tissues to textile tubes. This can probably only be realized with altered material properties. It would therefore be of interest to construct connection tubes or soft tissue connections with region-dependent and potentially anisotropic material properties. In the case of soft tissues used to create a laminar biological connection, it would be important to have large elongation properties for the muscle contraction in order to minimize strains at the connection site. In the case of muscles being directly attached to the endoprostheses, it would be important to reinforce the connection, thus increasing material stiffness and allowing the transfer of large tensile forces during the muscle contraction and joint movement [31]. A differentiated soft tissue attachment tube may offer a lower complication rate and shorter postoperative rehabilitation times for the patient until full range active joint motion is re-established. This would lead to a significantly shortened rehabilitation phase of patients after tumor or revision surgery. In future, soft tissue connection should therefore be developed for tumor prosthesis to achieve a reconstruction that is as close as possible to the original anatomical system and better for the surgical approaches. In view of increasing life expectancy in patients with malignant bone and soft tissue tumors [35], earlier exercise and thus mobilization of the diseased joint would decrease the risk for general postoperative complications. The regained mobility would also result in a tremendous increase in quality of life for patients.

\section{Limitations}

The testing at it stands does not entirely resemble physiological mechanisms of load but it represents the current standard of testing biological tissues. The muscles were subjected to passive strain, which is significantly different from active contraction concerning the forces exerted upon the extracellular matrix. Muscles and tendons are known to merge with the collagen type of the osseous periosteum by means of Sharpey fibers [36]. As the uniaxial strain exerted to this transition may be considered unphysiological, material failure related to avulsion phenomena are likely to happen. However, in most of the muscle samples, material failure was observed in the central part of the sample, indicating that this error only had a limited effect. Though the given tests are based on a small sample size and simplify physiological strain in vivo, they allow a comparison under standardized conditions between the different connection types. Moreover, in existing literature, a simplified representation of muscle origin and insertion is also commonly used [28, 33]. Therefore, our setup appears to be valid. Moreover, it is important to point out that the bone-muscle and Trevira ${ }^{\circ}$ samples showed scattered fiber orientations. Freezing the samples for storage might have influenced the material properties [19]. The suture of the muscles to the bones and/or attachment tubes will also likely impact the material properties of the compound [37]. However, this error may be regarded as systematic in our setup. Further limitations encompass potential effects of material slippage and estimating the samples' cross-sections on the basis of caliper measurements, which might likely influence material strain, stiffness and failure load. Further studies should be performed by taking more subjects with different age groups and genders.

\section{Conclusions}

Our experiments showed that higher forces were transmitted in the origin and insertion areas than in areas of flat soft tissue reconstruction using attachment tubes. The data indicate that the tested material allows reattaching muscles, but without reinforcing the insertion site. Therefore, attachment tubes with region-dependent and potentially anisotropic material behavior might be advantageous to optimize muscle-bone load transmission after surgery, which may allow lower complication rates and shorter physical recovery.

\section{Availability of data and materials}

The dataset supporting the conclusions of this article is available upon readers request - please contact corresponding author (nlshammer@googlemail.com).

\section{Open access}

This article is distributed under the terms of the Creative Commons Attribution 4.0 International License (http:// creativecommons.org/licenses/by/4.0/), which permits unrestricted use, distribution, and reproduction in any medium, provided you give appropriate credit to the original author(s) and the source, provide a link to the Creative Commons license, and indicate if changes were made. The Creative Commons Public Domain Dedication waiver (http://creativecommons.org/publicdomain/zero/ $1.0 /$ ) applies to the data made available in this article, unless otherwise stated.

\section{Abbreviations}

\%: percent; ${ }^{\circ} \mathrm{C}$ : centigrade; F: force; Hz: hertz; IL: Illinois; kN: kilonewton; kPa: kilopascal; MA: Massachusetts; min: minute; mm: millimeter; N: newton; USA: United States of America. 


\section{Competing interests}

The authors have no conflict of interest to declare. The authors alone are responsible for the content and writing of the paper.

\section{Authors' contributions}

SS, NH and PT planned and supervised the experiments. SS, MS and RM carried our the experiments. TW and RG provided technical support. SS, MS, RM and CS evaluated and interpreted the data. SS, RM, CS, NH and TP critically revised the manuscript. All authors read and approved the final manuscript.

\section{Acknowledgements}

The authors would like to thank Gustav F. Preller assisted in proofreading the manuscript as a native speaker. Robert McPhee helped illustrating figure one. We acknowledge support from the German Research Foundation (DFG) and Universität Leipzig within the program of Open Access Publishing.

\section{Author details}

'Department of Orthopedic, Trauma and Plastic Surgery, University of Leipzig, Liebigstraße 20, D-04103 Leipzig, Germany. ${ }^{2}$ Institute of Anatomy, University of Leipzig, Liebigstraße 13, D-04103 Leipzig, Germany. ${ }^{3}$ Department of Orthopaedic Surgery, Physical Medicine and Rehabilitation, University Hospital of Munich (LMU), Campus Grosshadern, Marchioninistraße 15, D-81377 Munich, Germany. ${ }^{4}$ Fraunhofer-Institut für Werkzeugmaschinen und Umformtechnik IWU, Medizintechnik, Nöthnitzer Str. 44, D-01187 Dresden, Germany. ${ }^{5}$ Department of Anatomy, University of Otago, Lindo Ferguson Building, 270 Great King St., Dunedin 9016, New Zealand.

\section{Received: 5 August 2015 Accepted: 25 March 2016}

\section{Published online: 06 April 2016}

\section{References}

1. Gosheger G, Gebert C, Ahrens H, Streitbuerger A, Winkelmann W, Hardes J. Endoprosthetic reconstruction in 250 patients with sarcoma. Clin Orthop Relat Res. 2006;450:164-71.

2. Raiss $P$, Kinkel $S$, Sauter U, Bruckner T, Lehner B. Replacement of the proximal humerus with MUTARS tumor endoprostheses. Eur J Surg Oncol. 2010;36:371-7.

3. Schoof B, Jakobs O, Gehrke T, Gebauer M. Proximal femoral reconstruction after aseptic loosening following proximal femoral replacement for Ewing sarcoma: a case report with one-year follow-up. Hip Int. 2014;24:103-7.

4. Gosheger G, Hillmann A, Lindner N, Rodl R, Hoffmann C, Burger H, Winkelmann W. Soft tissue reconstruction of megaprostheses using a trevira tube. Clin Orthop Relat Res. 2001:264-71.

5. Mavrogenis AF, Ruggieri P, Mercuri M, Papagelopoulos PJ. Megaprosthetic reconstruction for malignant bone tumors: complications and outcomes. J Long Term Eff Med Implants. 2008;18:239-51.

6. Hardes J, Ahrens H, Nottrott M, Dieckmann R, Gosheger G, Henrichs M, Streitburger A. Attachment tube for soft tissue reconstruction after implantation of a mega-endoprosthesis. Oper Orthop Traumatol. 2012;24:227-34.

7. Wirganowicz PZ, Eckardt JJ, Dorey FJ, Eilber FR, Kabo JM. Etiology and results of tumor endoprosthesis revision surgery in 64 patients. Clin Orthop Relat Res. 1999:64-74.

8. Roberts P, Chan D, Grimer RJ, Sneath RS, Scales JT. Prosthetic replacement of the distal femur for primary bone tumours. J Bone Joint Surg (Br). 1991; 73:762-9.

9. Hardes J, Gebert C, Schwappach A, Ahrens H, Streitburger A, Winkelmann W, Gosheger G. Characteristics and outcome of infections associated with tumor endoprostheses. Arch Orthop Trauma Surg. 2006:126:289-96.

10. Jeys $L$, Grimer $R$. The long-term risks of infection and amputation with limb salvage surgery using endoprostheses. Recent Results Cancer Res. 2009;179:75-84

11. Heisel C, Breusch SJ, Schmid G, Bernd L. Lower limb salvage surgery with MUTARS endoprostheses: 2 to 7 year results. Acta Orthop Belg. 2004;70:142-7.

12. Guo W, Yang $Y$, Tang $X$, Ji T. Endoprosthetic reconstruction after resection of the tumor of the proximal femur. Zhonghua Wai Ke Za Zhi. 2007:45:657-60.

13. Winkelmann W. Reconstruction of the proximal femur with the MUTARS(R) system. Orthopade. 2010;39:942-8.

14. Kuthe CD, Uddanwadiker RV, Ramteke A. Experimental evaluation of fiber orientation based material properties of skeletal muscle in tension. Mol Cell Biomech. 2014;11:113-28.
15. Takaza M, Moerman KM, Gindre J, Lyons G, Simms CK. The anisotropic mechanical behaviour of passive skeletal muscle tissue subjected to large tensile strain. J Mech Behav Biomed Mater. 2013;17:209-20.

16. van Ee CA, Chasse AL, Myers BS. Quantifying skeletal muscle properties in cadaveric test specimens: effects of mechanical loading, postmortem time, and freezer storage. J Biomech Eng. 2000;122:9-14.

17. Hammer N, Lingslebe U, Aust G, Milani TL, Hadrich C, Steinke H. Ultimate stress and age-dependent deformation characteristics of the iliotibial tract. J Mech Behav Biomed Mater. 2012;16:81-6.

18. Hammer N, Huster D, Fritsch S, Hadrich C, Koch H, Schmidt P, et al. Do cells contribute to tendon and ligament biomechanics? PLoS One. 2014;9: e105037.

19. Gottsauner-Wolf F, Grabowski JJ, Chao EY, An KN. Effects of freeze/thaw conditioning on the tensile properties and failure mode of bone-musclebone units: a biomechanical and histological study in dogs. J Orthop Res. 1995;13:90-5.

20. Komatsu F, Mori R, Uchio Y. Optimum surgical suture material and methods to obtain high tensile strength at knots: problems of conventional knots and the reinforcement effect of adhesive agent. J Orthop Sci. 2006;11:70-4.

21. Steinke H, Lingslebe U, Bohme J, Slowik V, Shim V, Hadrich C, Hammer N. Deformation behavior of the iliotibial tract under different states of fixation. Med Eng Phys. 2012;34:1221-7.

22. Jagodzinski M, Ettinger M, Haasper C, Hankemeier S, Breitmeier D, Hurschler C, Krettek C. Biomechanische analyse der press-fit-Fixierung von Kreuzbandtransplantaten. Unfallchirurg. 2010;113:532-9.

23. Evans WJ, Lexell J. Human aging, muscle mass, and fiber type composition. J Gerontol A Biol Sci Med Sci. 1995;50:11-6.

24. Muramatsu T, Muraoka T, Takeshita D, Kawakami Y, Hirano Y, Fukunaga T. Mechanical properties of tendon and aponeurosis of human gastrocnemius muscle in vivo. J Appl Physiol. 2001:90:1671-8.

25. Holzapfel BM, Rechl H, Lehner S, Pilge H, Gollwitzer H, Steinhauser E. Alloplastic reconstruction of the extensor mechanism after resection of tibial sarcoma. Sarcoma. 2011:2011:545104.

26. Pietschmann MF, Fröhlich V, Ficklscherer A, Hausdorf J, Utzschneider S, Jansson V, Müller PE. Pullout strength of suture anchors in comparison with transosseous sutures for rotator cuff repair. Knee Surg Sports Traumatol Arthrosc. 2008:16:504-10.

27. Pietschmann MF, Sadoghi P, Hauser E, Scharpf A, Gulecyuz MF, Schroder C, et al. Influence of testing conditions on primary stability of arthroscopic knot tying for rotator cuff repair: slippery when wet? Arthroscopy. 2011;27: 1628-36.

28. Pauwels F. Gesammelte Abhandlungen zur Biomechanik des Bewegungsapparates. Berlin: Springer; 1965.

29. Fukunaga $T$, Ichinose $Y$, Ito M, Kawakami $Y$, Fukashiro S. Determination of fascicle length and pennation in a contracting human muscle in vivo. J Appl Physiol. 1997:82:354-8.

30. Herbert RD, Moseley A, Butler JE, Gandevia SC. Change in length of relaxed muscle fascicles and tendons with knee and ankle movement in humans. J Physiol. 2002;539:637-45.

31. Kot BC, Zhang ZJ, Lee AW, Leung VY, Fu SN. Elastic modulus of muscle and tendon with shear wave ultrasound elastography: variations with different technical settings. PLoS One. 2012;7:e44348.

32. Muramatsu T, Muraoka T, Kawakami Y, Shibayama A, Fukunaga T. In vivo determination of fascicle curvature in contracting human skeletal muscles. J Appl Physiol (1985). 2002;92:129-34.

33. Benninghoff A. Lehrbuch der Anatomie des Menschen : Teil: Bd. 1., Allgemeine Anatomie und Bewegungsapparat: 2rd ed. München, Berlin, Wien: Urban \& Schwarzenberg; 1942.

34. Eby SF, Cloud BA, Brandenburg JE, Giambini H, Song P, Chen S, et al. Shear wave elastography of passive skeletal muscle stiffness: Influences of sex and age throughout adulthood. Clin Biomech (Bristol, Avon). 2014;30:22-7.

35. Jansen L, Gondos A, Eberle A, Emrich K, Holleczek B, Katalinic A, Brenner H. Cancer survival in Eastern and Western Germany after the fall of the iron curtain. Eur J Epidemiol. 2012;27:689-93.

36. Leonhardt H, Tillmann B, Töndury G, Zilles K. Rauber/kopsch, anatomie des menschen, vol. 2. Paris: Thieme; 1987. p. 272-3.

37. Müller $P E$, Gülecyüz MF, Schröder $C$, Fröhlich V, Häuser E, Huttel U, Pietschmann MF. Biomechanische aspekte der rotatorenmanschettennaht: einfluss von nahtmaterial, knotentechnik und nahttechnik auf die primärstabilität. Sport-Orthop-Sport-Traumatol-Sports Orthop Traumatol. 2013;29:45-8 